\title{
Novel Program to Promote Critical Thinking among Higher Education Students: Empirical Study from Saudi Arabia
}

\author{
Huda Umar Alwehaibi ${ }^{1}$ \\ ${ }^{1}$ Department of Curriculum and Instruction, College of Education, Princess Noura Bint Abdulrahman Univetsity, \\ Riyadh, Saudi Arabia \\ Correspondence: Huda Umar Alwehaibi, Department of Curriculum and Instruction, College of Education, \\ Princess Noura Bint Abdulrahman Univetsity, Riyadh, Saudi Arabia. Tel: 966-5-5522-7138. E-mail: \\ Hudawh@yahoo.com
}

Received: April 19, 2012 Accepted: May 25, 2012 Online Published: August 30, 2012

doi:10.5539/ass.v8n11p193 URL: http://dx.doi.org/10.5539/ass.v8n11p193

Novel program to promote critical thinking among higher education students: Empirical study from Saudi Arabia

\begin{abstract}
Critical thinking is important for shaping the way students learn and think. However, there is a need for a systematic direct instruction aimed at developing effective critical thinking skills.

This study aims to investigate the effect of a proposed critical thinking program on developing the critical thinking skills of college students.

During a 5-week intervention, 80 second-year female students of the English Department of Princess Noura Bint Abdulrahman Univetsity (Riyadh, Saudi Arabia) underwent this program during the thinking skills course. The effectiveness of the program was examined using a critical thinking assessment instrument that evaluated five critical thinking skills: causal explanation, determining the reliability of sources, argument, prediction, and determining parts-whole relationships.

The data demonstrated statistically significant gains in the five critical thinking skills tested.

Thus, this study provides a framework for creating teaching methods that provide effective direct instruction for the development of critical thinking skills of college students.
\end{abstract}

Keywords: methods of teaching, thinking skills, critical thinking programs, teaching strategies, college students

\section{Introduction}

It is widely recognized that critical thinking is an essential competency that can play a significant role in shaping the way students learn and think in today's information age. Learning to think critically and creatively is a lifelong skill with broad applications both inside and outside the classroom. Therefore, Fisher (2007) and Fisher and Scriven (1997) argue that critical thinking should be seen as a basic academic competency, akin to reading and writing, which needs to be taught. Beyer (2001a) claims that teaching thinking skills is worth considering for the crucial role it plays in teaching, learning, and daily life.

Critical thinking is different from merely thinking. While Ennis (2001) roughly defines it as reasonable and reflective thinking that is focused on deciding what to believe or do, Nosich (2009) sees it as more than making such decisions; it is a metacognitive, reasonable, and authentic process that involves high standards and such concerns as accuracy, relevance, and depth. Paul and Elder (2006) interpret critical thinking as "thinking explicitly aimed at well-founded judgment, utilizing appropriate evaluative standards in an attempt to determine the true worth, merit or value of something" (p. xx). Such a definition implies that it has three components: analysis, evaluation, and creativity. Similarly, Fisher (2007) defines it as "a kind of evaluative thinking-which involves both criticism and creative thinking and which is particularly concerned with the quality of reasoning or argument which is presented in support of a belief or a course of action" (p. 13). 
Critical thinking may also be characterized as a purposeful mode of thinking about content, a subject, or a problem, which involves different components. According to Nosich (2009), it can be seen as having three parts: asking questions, answering those questions by reasoning them out, and believing the results of the reasoning. Similarly, Paul \& Elder (2006) specify the attitudes and approaches that good critical thinkers habitually seem to exhibit: they ask crucial questions, gather and assess relevant information, think objectively, communicate effectively, and come carefully to well-reasoned conclusions about and solutions to complex problems. What these definitions and conceptions of critical thinking have in common, although the terminology has changed slightly over the years, is that they comprise a number of skills and mental processes. While Costa (2001) stresses the importance of developing certain "habits of mind" necessary to becoming good critical thinkers, Swartz, Arthur, Barry, Rebecca, \& Bena (2008) suggest replacing the old terminology of "thinking skills," or thinking dispositions and habits of minds, with the ultimate goal, which is skilful thinking.

Although the consensus is that critical thinking is a human cognitive process that enables one to use a core set of cognitive skills, a fair amount of controversy surrounds which skills should be taught to develop such thinking. Most researchers working in the critical thinking tradition have produced a list of thinking skills or abilities that they see as basic to critical thinking. In 1990, a group of international experts identified the cognitive skills and mental abilities involved in critical thinking and included interpretation, analysis, evaluation, inference, explanation, and self-regulation at the very core of critical thinking (Facione, 1990). Swartz and Parks (1994) claim that development of critical thinking requires engaging students in various types of thinking. Thinking skilfully and carefully about causal explanation, prediction, generalization, reasoning, and the reliability of sources will not only develop the students' critical thinking skills and abilities, but will also become essential in their lives and future professional work. Borich (2006) points out that all models of critical thinking skills have key elements in common, and they include a range of mental processes and skills, such as comparing, classifying, analyzing, identifying causes, predicting, and evaluating.

Development of thinking skills addresses many complex issues in teaching and learning. Swartz (2001) believes that teaching skilful thinking not only enhances students' thinking abilities and learning in the content areas but also greatly improves the quality of their lives, including their professional work, after they leave school. Such thinking also improves their self-image and their motivation to learn. Beyer (2001) indicates that mastery of at least four thinking skills - comparing, classifying, sequencing, and predicting - is essential for students to become effective readers, writers, and learners. Paul and Elder (2006) claim that critical thinking provides the tools for the mind that people generally need to think things through for both studying and daily life. As thinking skills develop, students gain instruments that can be used effectively to reason better through the thinking tasks implicit in their future goals. Brookhart (2010) concluded, after reviewing a number of studies on the impact of critical thinking on teaching and learning, that using assignments and assessments that require intellectual work and critical thinking is associated with increased student achievement.

A considerable body of research exists on the effectiveness of teaching critical thinking skills. A major finding that emerged from Reed's study (1998) indicates that community college students' abilities to think historically and critically improved in a U.S. history course when a critical thinking model was integrated into the course. Higgins, Hall, Baumfield, \& Moseley (2005) have reported on the results of a quantitative synthesis (meta-analysis) of studies that evaluated the impact of the use of thinking skills programs and approaches on students' cognition, achievement, and attitudes. Higgins and his colleagues examined 29 studies from all over the world, mostly from the United States and the United Kingdom, that were used in primary and secondary schools in literacy, mathematics, and science. Higgins et al.'s analysis supports the conclusion that thinking skill interventions are effective in improving students' thinking, content area achievement, and motivation. Through introducing his focused critical thinking training in a San Diego area twelfth-grade rhetoric and composition class, Scanlan (2006) reported dramatic improvement in students' composition in all of the five key areas in writing that were measured in the study. Critical thinking skills in Savich's study (2008) were shown to be effective for high-school students in achieving a more in-depth and meaningful understanding of history, and resulting as well in higher scores on tests, quizzes, and assignments. Sezer (2008) points out that emphasis on critical thinking, even in one course, can have positive effects on students' attitudes. Galloway (2009) reported that students' writing achievement improved significantly with the use of skilful thinking processes and writing maps. Furthermore, Bensley, Crowe, Bernhardt, Buckner, \& Allman (2010) found that a group of college students who received explicit critical thinking skills instruction in a research methods course showed significantly greater gains in their argument analysis skills than the groups receiving no explicit critical thinking instruction. 
Integrating thinking skills instruction in the English as a foreign or second language (EFL/ESL) curricula has been emphasized by educators and researchers in teaching EFL/ESL, for its effectiveness in developing learners' critical thinking skills and EFL skills as well. Research evidence has demonstrated that language and thinking competencies shape each other (Rojas, 2001). Renner (1996) claims that higher order thinking skills promote higher order learning skills, which in turn enable students to reach higher levels of English language proficiency. Davidson and Dunham (1996) found that 36 Japanese students in a women's junior college in Osaka, Japan, who received additional training in critical thinking skills scored significantly higher on the Ennis-Weir Critical Thinking Essay Test in EFL classes, compared with a group who received only content-based intensive English instruction. Through designing and implementing a content-based junior high school EFL syllabus, Liaw (2007) reported significant gains in the students' English language proficiency test scores, besides critical thinking skills and content area knowledge mastery. A study conducted by Sokol, Oget, Sonntag, \& Khomenko (2008) showed that upper high school students in Latvia, working with the thinking approach to foreign language teaching and learning, demonstrated a significant increase in their inventive thinking skills in comparison with the control group.

The findings and recommendations of the research cited here suggest that students' academic achievement and their quality of thinking can be improved if schools adopt critical thinking instruction and its associated strategies and techniques to develop college students' critical thinking skills in various courses.

\section{Context of the Problem}

Currently, teachers and university professors have become highly interested in the teaching of thinking skills through the application of various techniques and strategies that would help in building students' cognitive development. Fisher (2007) points out that although many teachers claim to teach their students indirectly how to think, educators doubt the effectiveness of such teaching because "most students simply do not pick up the thinking skills in question" (p. 1). Paul, Linda, \& Ted (1997) found that most teachers in California have only a vague understanding of what critical thinking is and how to teach it successfully; while $89 \%$ of the teachers sample claimed critical thinking to be a primary objective of their instruction, only $9 \%$ were clearly teaching with a focus on critical thinking on a typical day in class. Several studies as well reported lack of knowledge or understanding of critical thinking and how it should be taught and practiced among school teachers and university professors (Bataineh \& Alazzi, 2009; Innabi \& El Sheikh, 2007; Stapleton, 2011; Thurman, 2009). As a result, a significant number of secondary school and college students do not have effective higher-order thinking skills required for success in postsecondary education or in their careers, as reported in a literature review by Beyer (2001b).

These findings indicate that effective instruction for critical thinking is not given on a wide scale, and hence, there is a need for continuing systematic direct instruction in the thinking skills. Within the context of their study's findings, Mahyuddin, Pihie, Elias, \& Konting (2004) suggest that educators and curriculum planners should consider teaching thinking skills exclusively as a subject. Reed (1998) points out that the most essential implication of her study is the importance of recognizing the need for explicit and intense teaching of critical thinking. Cotton (1991) as well calls for direct instruction in critical and creative thinking skills, because they are teachable, and these skills are generally not well developed in the students.

Although the usefulness of various critical thinking interventions and programs has been reported in the past, there are shortcomings of some published or reported critical thinking programs by other researchers: "the research is not all in, relative to teaching thinking skills. Nor may it ever be. There are still gaps, even apparent contradictions" (Beyer, 2001b, p. 279). Hatcher (2006) believes that there are numerous important questions that need to be examined if the goal of teaching critical thinking is to be met, the most important of which are (1) how critical thinking skills are best taught and (2) which approach is most effective for teaching them. The implications that emerged from Reed's study (1998) stress the importance of identifying the best methods of critical thinking instruction. What is lacking is a college-level critical thinking program that fills in these gaps and focuses on skills and dispositions essential for a student's academic success and suggests effective methods and strategies for developing such skills.

In Saudi Arabia, higher education has achieved remarkable progress both in quality and quantity. It has recently adopted radical changes, which in turn led to new restructuring of the universities to adapt with the orientations of the Saudi and international labour markets. This reconstruction is achieved across a wide range of procedures and programs. Curricula of the new programs stress the importance of developing the students' thinking skills as valued educational goals where students can be trained to make sense of new information and not just acquisition of knowledge. Realizing this need to develop students' thinking skills, many universities in the kingdom have 
designed courses that aim at developing various types of thinking skills independently of the subject-based curriculum, assuming that mastery of such skills will enhance content learning and will become a lifestyle. However, although instructors are urged to teach critical thinking, Aldegether's study (2009) revealed that faculty members teaching at five teacher colleges in Saudi Arabia occasionally use critical thinking methods and are unsure of the constructs or elements of critical thinking although they have favourable opinions about critical thinking.

At Princess Noura Bint Abdulrahman Univetsity, the critical thinking skills specified in the thinking skills course are not effectively emphasized, and their teaching strategies are not appropriate for developing these skills. Little is known about whether the critical thinking component of the course, which is expected to promote critical thinking skills, is actually effective. It has also been observed by many instructors in the English department that students struggle with mastery of thinking skills in general and critical thinking in particular. This problem could be attributed to many factors, including inadequate selection of the critical thinking skills to be developed and the teaching techniques and strategies adopted for teaching and practicing the required skills.

In an effort to work on a solution, a critical thinking program is proposed here, showing how college-level critical thinking should be defined and which skills and dispositions essential to students' academic success need to be cultivated through direct and explicit instruction. The program was tried on a sample of second-year EFL students, and the teaching techniques and strategies used to develop their critical thinking skills are demonstrated here, along with the results of the study.

\section{Research Questions and Hypotheses}

The present study attempted to answer the following questions:

1. What is the effect of the suggested critical thinking program on developing the critical thinking skills of second-year EFL students?

2. What is the effect of the suggested critical thinking program on developing each of the following critical thinking skills:

- Causal explanation

- Determining the reliability of sources

- Argument

- Prediction

- Determining parts-whole relationships

The hypotheses proposed for this study are as follows:

1. There will be no statistically significant differences (at the $>.05$ level) between the total mean gain scores of the students on the pre-test and those of the same students on the post-test of the critical thinking skills.

2. There will be no statistically significant differences (at the $>.05$ level) between the mean gain scores of the students on the pre-test and those of the same students on the post-test for each critical thinking skill.

\section{Methodology}

\subsection{Design and Participants}

The present study investigated the effect of a proposed program for developing the critical thinking skills of second-year college students in the English Department of the Faculty of Arts at Princess Noura Bint Abdulrahman Univetsity. The quasi-experimental design adopted in this study was the one-group pre-test/post-test design (Ary, Lucy, Asghar, \& Christine, 1996). A sample population of 80 second-year female students in the English Department, 40 students in each class, was randomly selected. The researcher taught these students critical thinking skills through a course called "Developing Thinking Skills" through the suggested program for five weeks, four hours per week.

The mean age of the students attending the course was 20 years. To be admitted to the English Department, students are administered entry placement tests, and they have to pass written and oral English proficiency tests. Only students officially matriculated for the first semester of the academic year 2009-2010 participated, and the students were almost all at the same skill level, as measured by the pre-test.

\subsection{Instrumentation}

The critical thinking program suggested in this study is aimed at developing and enhancing college students' critical thinking skills through explicit and direct teaching of thinking. The aim and objectives of the program 
were discussed with the students during the first meeting, and the significance of critical thinking skills as lifelong skills was established.

The program covered five fundamental critical thinking skills ranging from simple compare and contrast, which is introductory, to more complex thinking processes, such as prediction. Selection of the skills was based on their suitability to the level of second-year college students in the English Department and their significance to students' learning and daily life. They comprised the following:

1. Comparing and contrasting

2. Determining parts-whole relationships

3. Determining the reliability of sources

4. Causal explanation

5. Prediction

\subsection{Teaching Method}

The five-week intervention, called "Teaching of Thinking," aimed at enhancing the students' critical thinking skills through explicit teaching of those skills. The teaching of thinking, as explained by Costa (2001), means instructing students directly in the cognitive skills, operations, and dispositions, which includes teaching the steps and strategies of thinking skills, as well as "habituating those attitudes, dispositions, or habits of mind that characterize effective skilful thinkers" (p. 355). Therefore, the researcher instructed the students directly in the processes of thinking during a separate self-contained course called "Developing Thinking Skills." The methods and strategies of instruction were based on the thinking skills frameworks developed by Swartz and Parks (1994). For learning the skills, students chose topics and situations, based on their interests and needs, that were not related to the curriculum. The stages and procedures used were as follows:

\subsubsection{Introducing Thinking Skill and Its Significance}

The introduction activated the students' prior knowledge and experience with the skill, and demonstrated the value and usefulness of performing it skilfully in real-life situations. Some examples are as follows:

- Finding out what caused something is called "causal explanation." This involves thinking about the possible causes of a problem, for example, to find the best solution to it.

- In our information age, how important is it to discern about the reliability of the information you get from the media, including the Internet?

- Prediction is an important skill you need to practice in making decisions. What predictions could you make before accepting a new job offer?

\subsubsection{Active Thinking Involving Verbal Prompts and Graphic Maps}

In collaborative groups, the students started practicing the thinking skills through real-life examples and topics, which they either chose or the teacher suggested. The students were guided in the thinking activity by skilful use of thinking maps and graphic organizers. Thinking maps are sets of questions that students should ask themselves when trying to think skilfully in various ways. They include open-ended questions, such as the following:

- Considering your college, what smaller things make up the whole? What is the function of each part?

- List the factors that are relevant to the reliability of Internet articles about H1N1 (Swine Flu) vaccine.

- What are the possible causes of the students' low level in English? Being overweight? Divorce?

Graphic organizers are instructional tools for organizing ideas and information used to highlight key points in the thinking skill being practiced. Samples of students' writings in graphic organizers developed by Swartz and Parks (1994) are shown in Figure 1.

\subsubsection{Thinking about Thinking (Metacognition)}

Metacognition means thinking about one's own thinking. It enables us to be conscious of our own steps and strategies when we think, and to evaluate these strategies in order to modify them if they do not work well (Swartz et al., 2008). At this stage, the students were asked direct questions about their own thinking in order to reflect on it. For example:

- What kind of thinking have you already done?

- How do you decide that a source of information is unreliable? 
- How is the compare-and-contrast process different from merely identifying similarities and differences? Is it helpful in thinking about things?

\subsubsection{Application of the Thinking Process (Immediate Transfer)}

This process means transferring the application of a skill to new contexts. The students were asked to apply the thinking process to other examples within the same class session or the next class. For this exercise, a thinking skill applied earlier can be reintroduced in a different context (Beyer, 2001b). The students were guided to transfer the thinking process to daily life in a way that involved less teacher prompting than in the actively thinking stage. This transfer process could serve as an assessment activity by means of such questions as the following:

- After reading this newspaper article, what message does the author want to convey about the use of weasel words in advertisement?

- Think about some cosmetics you would like to buy and plan what sources you will use to obtain the most reliable information about the best products for your skin.

- Use skilful prediction to determine the impact of running out of oil in Saudi Arabia.

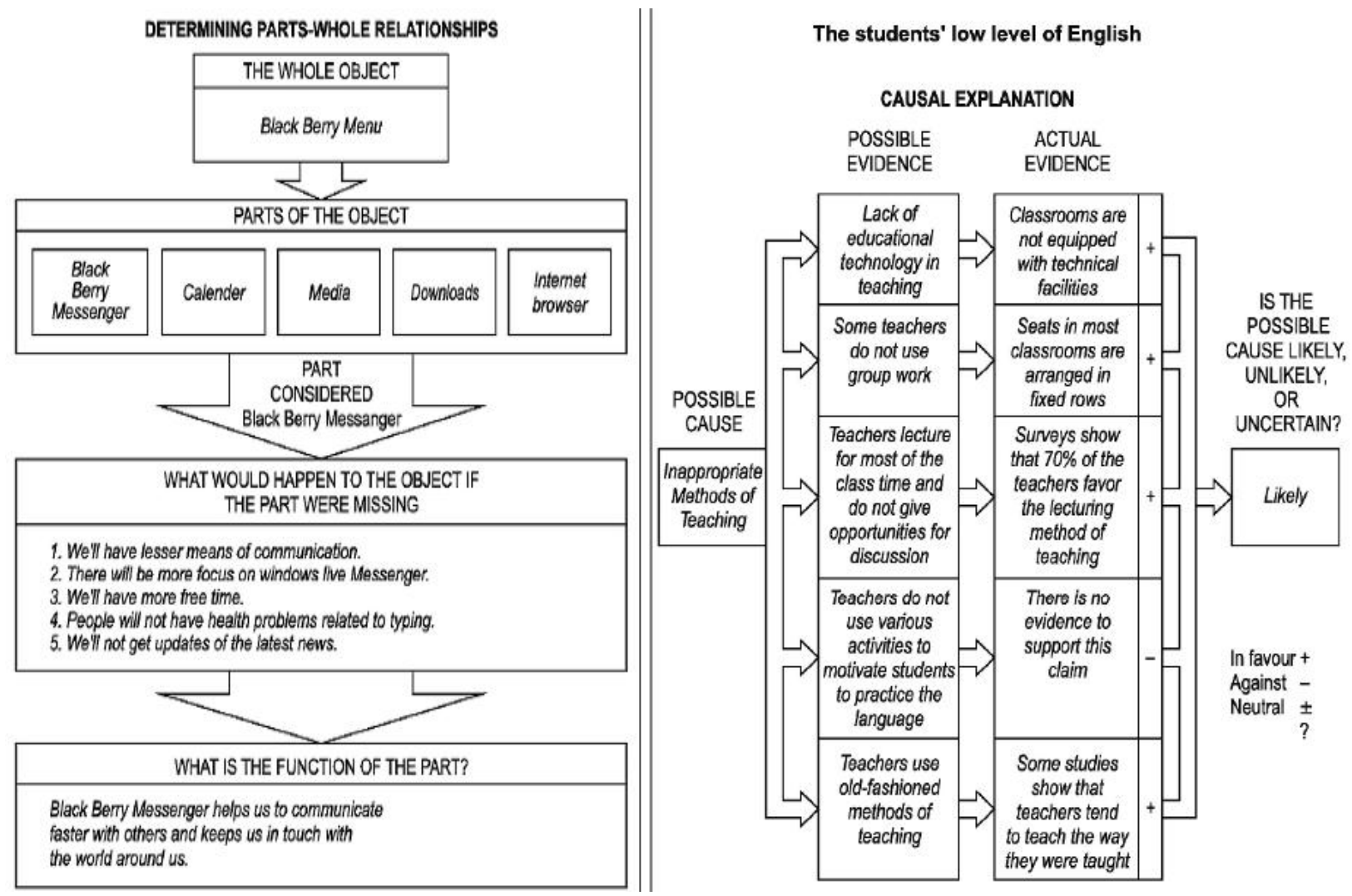

Figure 1. Samples of students' writings in graphic organizers

\subsection{Critical Thinking Assessment Instrument}

The researcher used the Critical Thinking Assessment Instrument CT007, developed by the National Center for Teaching Thinking (NCTT-USA), as a pre- and post-test to assess the students' development in critical thinking skills. This diagnostic instrument is intended to indicate reliably students' skills in critical thinking. For this study, the content of some items has been modified to suit the students' culture and background knowledge. The critical thinking instrument consists of four main parts, each containing a number of items that assess different critical thinking skills.

Table 1 shows the types of skills covered in each item. The instrument was administered to all participants before and after the experiment. The items remained secure; the students were not informed about how well they did on the pre-test, and the scoring was blind. 
Table 1. Distribution of skills on the test items

\begin{tabular}{|c|c|c|c|c|c|c|c|c|c|c|c|c|c|}
\hline \multirow{3}{*}{$\begin{array}{l}\text { The critical } \\
\text { thinking skill }\end{array}$} & \multicolumn{4}{|c|}{ Part 1} & \multicolumn{5}{|c|}{ Part 2} & \multicolumn{2}{|c|}{ Part 3} & \multicolumn{2}{|c|}{ Part 4} \\
\hline & Item & Item & Item & Item & Item & Item & Item & Item & Item & Item & Item & Item & Item \\
\hline & 1 & 2 & 3 & 4 & 1 & 2 & 3 & 4 & 5 & 1 & 2 & 1 & 2 \\
\hline $\begin{array}{c}\text { Causal } \\
\text { Explanation }\end{array}$ & $\mathrm{x}$ & & & & & & $\mathrm{x}$ & & $\mathrm{x}$ & & $\mathrm{x}$ & & $\mathrm{x}$ \\
\hline $\begin{array}{l}\text { Reliability } \\
\text { of Sources }\end{array}$ & $\mathrm{x}$ & $\mathrm{x}$ & & $\mathrm{x}$ & & & & & & & & & $\mathrm{x}$ \\
\hline Argument & & & & & & & & & $\mathrm{x}$ & & $\mathrm{x}$ & & \\
\hline Prediction & & & & & & & & & & & & & \\
\hline & & & & & & & $\mathrm{x}$ & & & & & & \\
\hline $\begin{array}{l}\text { Parts-whole } \\
\text { Relationship }\end{array}$ & & $\mathrm{x}$ & & & & & & & & & & & \\
\hline
\end{tabular}

4.5 Data Analysis, Results, and Discussion

The pre- and post-tests, which covered five critical thinking skills - causal explanation, reliability of sources, argument, prediction, and determining parts-whole relationships - were administered to all participants before and after the experiment to determine the effect of the suggested program on developing their critical thinking skills.

\subsection{Hypotheses Testing}

The first hypothesis stated, "There will be no statistically significant differences (at a $>.05$ level) between the total mean gain scores of the students on the pre-test and those of the same students on the post-test of the critical thinking skills." To test this hypothesis, a $t$-test for paired samples was used to compare the total mean gain scores of the students on the pre-test and those of the post-test for critical thinking. Eta square $\left(\eta^{2}\right)$ was also used to compute the effect size of the critical thinking program on the total mean gain scores of the paired samples in critical thinking skills. The results are presented in Table 2 .

Table 2. Results of the t-test for the total mean gain scores of the paired samples on the pre- and post-tests for critical thinking skills

\begin{tabular}{cccccc}
\hline $\begin{array}{c}\text { Variables } \\
\text { (Skills and sub-skills) }\end{array}$ & Mean & $\begin{array}{c}\text { Standard } \\
\text { Deviation }\end{array}$ & t-value & $\begin{array}{c}\text { Sig. } \\
\text { two-tailed }\end{array}$ & $\begin{array}{c}\text { Eta`2 }_{\text {Eta Square }} \\
\text { Total Score (Pre) }\end{array}$ \\
Total Score (Post) & 19.88 & 4.00 & 16.06 & 0.000 & 0.77 \\
\hline
\end{tabular}

The data presented in Table II demonstrates that there is a significant difference at the 0.01 level between the total mean gain scores of the students on the pre-test and those of the same students on the post-test for critical thinking skills, in favour of the post-test. The impact of the critical thinking instruction was also measured using effect sizes; $\eta^{2}=0.77$ indicates a considerable effect size for the critical thinking treatment on critical thinking skills.

Figure 2 further illustrates the significant difference between the total mean gain score of the two applications of the critical thinking tests and the significant increase in the students' total score on the post-test. 


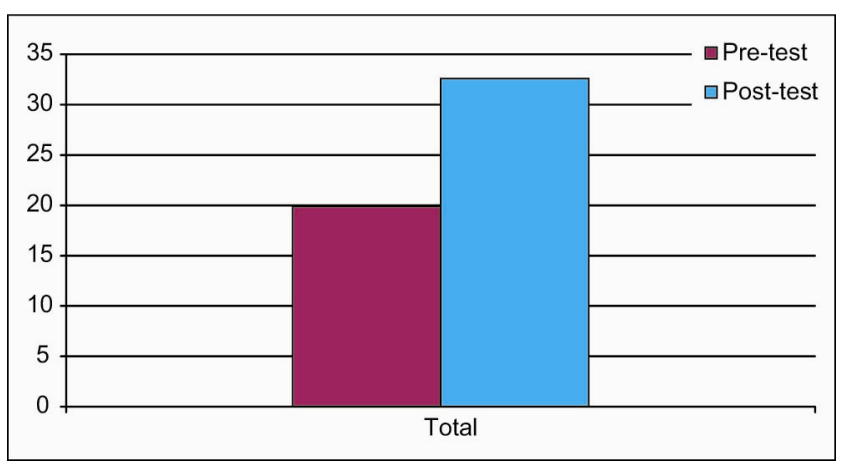

Figure 2. Total mean gain scores of the students on the pre- and post-tests for critical thinking skills

The second hypothesis states, "There will be no statistically significant differences (at the >.05 level) between the mean gain scores of the students on the pre-test and those of the same students on the post-test for each critical thinking skill." A summary of the results is reported in Table 3.

Table 3 Results of the t-test for the mean gain scores of the paired samples on the pre- and post-test for each critical thinking skill

\begin{tabular}{|c|c|c|c|c|c|}
\hline $\begin{array}{c}\text { Variables } \\
\text { (Skills and sub-skills) }\end{array}$ & Mean & $\begin{array}{l}\text { Standard } \\
\text { Deviation }\end{array}$ & $t$-Value & $\begin{array}{c}\text { Sig. } \\
\text { two-tailed }\end{array}$ & $\begin{array}{c}\text { Eta }^{\wedge} 2 \\
\text { Eta Square }\end{array}$ \\
\hline Causal Explanation (Pre) & 8.88 & 2.54 & \multirow{2}{*}{12.17} & 0.000 & \multirow{2}{*}{0.65} \\
\hline Causal Explanation (Post) & 13.29 & 3.42 & & $(0.01)$ & \\
\hline Reliability of Sources (Pre) & 5.41 & 1.57 & \multirow{2}{*}{12.09} & 0.000 & \multirow{2}{*}{0.65} \\
\hline Reliability of Sources (Post) & 10.18 & 3.58 & & $(0.01)$ & \\
\hline Argument (Pre) & 2.30 & 0.60 & \multirow{2}{*}{6.81} & 0.000 & \multirow{2}{*}{0.37} \\
\hline Argument (Post) & 3.38 & 1.41 & & $(0.01)$ & \\
\hline Parts-Whole Relationship (Pre) & 2.08 & 0.97 & \multirow{2}{*}{9.13} & 0.000 & \multirow{2}{*}{0.51} \\
\hline Parts-Whole Relationship (Post) & 3.15 & 0.97 & & $(0.01)$ & \\
\hline Prediction (Pre) & 1.21 & 0.57 & \multirow[t]{2}{*}{10.38} & 0.000 & \multirow[t]{2}{*}{0.58} \\
\hline Prediction (Post) & 2.60 & 1.15 & & & \\
\hline
\end{tabular}

Table 3. illustrates, first, that the students scored significantly higher on the post-test at the 0.01 level on each critical thinking skill, as outlined above. The value of $\eta 2$ also shows a significant effect size of the critical thinking treatment on the score of each skill. Figure 3 further illustrates the significant difference between the mean gain score of the two applications of the critical thinking test and the significant increase in the students' score on each skill on the post-test.

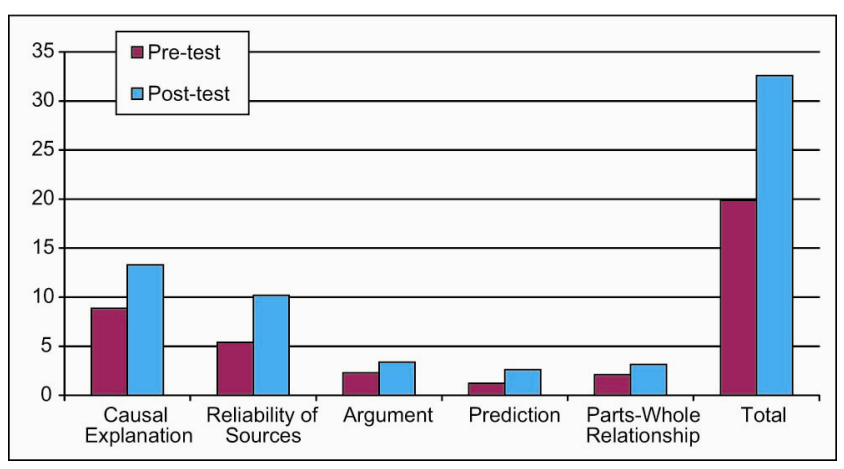

Figure 3. Mean gain scores of the students on the pre- and post-test for each critical thinking skill 
Second, Table III shows that the students scored significantly higher on the causal explanation skill than they did on the other skills, followed by reliability of sources, argument, and parts-whole relationship on the post-test at the 0.01 level. The prediction skill was the least affected one by the suggested program; however, the students' score on the post-test for this skill was significantly high at the 0.01 level. The value of $\eta 2$ also shows a significant effect size of the critical thinking instruction on the score of each skill.

Third, and finally, although the critical thinking program did not include any instruction for the argument skill, the students developed this skill significantly.

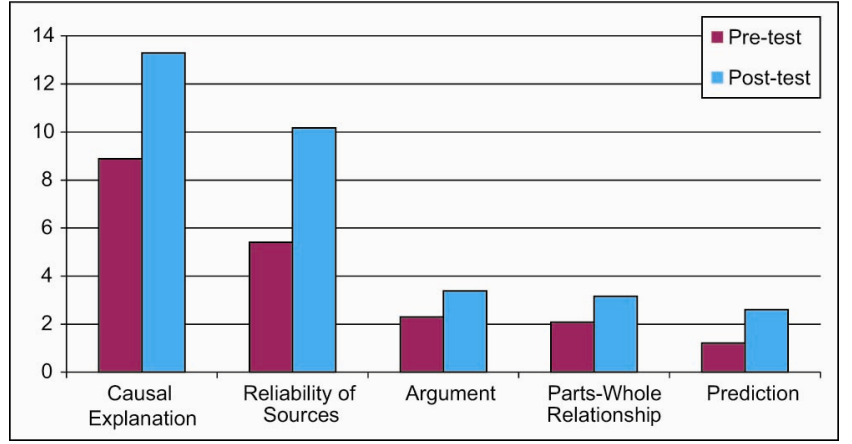

Figure 4. The critical thinking skills most affected by the program

\section{Discussion of the Results and Conclusion}

The statistical analysis of the data using the $t$-test and $\eta^{2}$ showed that the suggested critical thinking program had a significantly positive effect on developing second-year college students' critical thinking skills, as the $t$-value was 16.06. This finding rejects the first hypothesis. The analyses of the data also showed that the suggested critical thinking program was effective in developing each of the critical thinking skills included in the program as well as the argument skill, which was not addressed in the same program. The students attained significantly higher scores on each critical thinking skill on the post-test than they did on the pre-test. Thus, the second hypothesis was also rejected.

Such results support the findings from various researchers that have revealed the positive impact of critical thinking programs and approaches on developing students' critical thinking skills (Bensley et al., 2010; Higgins et al., 2005; Miri, Ben-Chaim, \& Zoller, 2007; Reed, 1998; Savich, 2008). In general, the students' development in the critical thinking skills taught through the designed instruction was highly significant.

These results support as well the effectiveness of teaching critical thinking skills in foreign language contexts as shown in the studies of Davidson and Dunham (1996), Liaw (2007), and Sokol, Oget, Sonntag, \& Khomenko (2008). The reported findings imply that critical thinking skills can successfully be taught and learned as an integral part of academic EFL/ESL instruction.

Several possibilities exist to provide reasons why such instruction resulted in students' scoring higher on the critical thinking post-tests. The use of graphic organizers and thinking maps could have contributed to the superiority of the critical thinking instruction. Hyerle (2001) points out that visual tools are the most compatible and effective for moving students from the basic organization of information, to basic skills instruction and content learning, as well as thinking in patterns and systems. Moreover, the systematic use of thinking maps leads to successful improvement in test results and quality indicators (Hyerle, 2000).

Another possibility could have been the use and practice of higher-order thinking strategies, the focus of the program, which led to developing critical thinking. Miri et al. (2007) suggest that the purposeful and persistent practice of higher order thinking strategies, such as dealing in class with real-world problems, encouraging open-ended discussions, and fostering inquiry-oriented experiments-all practices applied in the present study - would lead to consequent development of critical thinking capabilities. Brookhart (2010), in her review of a number of studies conducted in the field of critical thinking and its impact on teaching and learning, concluded that using assignments and assessments that require intellectual work and critical thinking is associated with increased student achievement.

Similarly, engaging students in metacognitive activities could have been another factor that led to developing critical thinking skills. The metacognition effect is relatively greater than other researched educational interventions, as shown in a number of studies. Metacognitive strategies and activities have a positive effect on a 
number of variables related to teaching and learning, such as better retention of content material (Coskun, 2010; Smith, Rook, \& Smith, 2007), improvement in mathematical problem-solving achievement and metacognitive skills (Ozsoy, 2009), and enhancement of the critical thinking ability of university students (Kelly \& Irene, 2010; Magno, 2010). The reported studies indicate that the need to cultivate students' use of metacognitive strategies in the learning process should be emphasized.

Based on the above-mentioned discussion, it can be concluded that a well-structured critical thinking program incorporating various teaching methods and strategies that promote students' critical thinking should be considered an effective instructional tool for developing college students' critical thinking skills. The findings of this study have important implications for classroom instruction. It describes a framework for effective direct instruction with its teaching techniques and strategies for introducing thinking skills, guiding their practice, and teaching students to transfer these skills to other contexts. It is thus recommended that such critical thinking skill approaches and programs be encouraged and supported for their efficacy in developing various critical thinking skills.

\section{References}

Al-Degether, R. (2009). Teacher educators' opinions and knowledge about critical thinking and the methods they use to encourage critical thinking skills in five female teacher colleges in Saudi Arabia. PhD diss., University of Kansas.

Ary, D., Lucy C. J., Asghar, R., \& Christine, K. S. (1996). Introduction to research in education. New York, NY: Harcourt Brace College.

Bataineh, O., \& Alazzi, K. (2009). Perceptions of Jordanian secondary schools teachers towards critical thinking. Education Resources Information Center. ERIC No. EJ869429.

Bensley, D., Crowe, D., Bernhardt, P., Buckner, C., \& Allman, A. (2010). Teaching and assessing critical thinking skills for argument analysis in psychology. Education Resources Information Center. ERIC No. EJ883208.

Beyer, B. (2001a). Teaching thinking skills: Defining the problem. In A. L. Costa (Ed.), Developing minds: A resource book for teaching thinking (pp. 35-40). Alexandria, VA: Association for Supervision and Curriculum Development.

Beyer, B. (2001b). What research says about teaching thinking skills. In A. L. Costa (Ed.), Developing minds: A resource book for teaching thinking (pp. 275-282). Alexandria, VA: Association for Supervision and Curriculum Development.

Borich, G. (2006). Introduction to thinking skills. In A. C. Ong, \& G. Borich (Eds.), Teaching strategies that promote thinking: Models and curriculum approaches (pp. 15-25). Singapore: McGraw-Hill Education.

Brookhart, S. (2010). How to assess higher order thinking skills in your classroom. Alexandria, VA: (ASCD) Association for Supervision and Curriculum Development.

Coskun, A. (2010). The effect of metacognitive strategy training on the listening performance of beginner students. Education Resources Information Center. ERIC No. ED509339.

Costa, A. (2001). Teaching for, of and about thinking. In A. L. Costa (Ed.), Developing minds: A resource book for teaching thinking (pp. 354-358). Alexandria, VA: Association for Supervision and Curriculum Development.

Cotton, K. (1991). Teaching thinking skills. Portland, USA: School Improvement Research Series (SIRS).

CT007. National Center for Teaching Thinking. Newton Center, MA 02459 USA. Retrieved November 4, 2009, from http://www.nctt.net

Davidson, B., \& Dunham, R. (1996). Assessing EFL student progress in critical thinking with the Ennis-Weir critical thinking essay test. Education Resources Information Center. ERIC No. ED403302.

Ennis, R. (2001). Goals for a critical thinking curriculum and its assessment. In A. L. Costa (Ed.), Developing minds: A resource book for teaching thinking (pp. 44-46). Alexandria, VA: Association for Supervision and Curriculum Development.

Facione, P. (1990). Critical thinking: A statement of expert consensus for purposes of educational assessment and instruction. Research Findings and Recommendations. Education Resources Information Center. ERIC No. ED315423. 
Fisher, A. (2007). Critical thinking: An introduction. Cambridge, England: Cambridge University Press.

Fisher, A., \& Michael, S. (1997). Critical thinking: Its definition and assessment. Point Reyes, CA: Edgepress.

Galloway, B. (2009). Thinking and writing. Wellington, New Zealand: Northwest EHSAS Cluster.

Hatcher, D. (2006). Stand-alone versus integrated critical thinking courses. Journal of General Education, 55(3-4), 247-272. http://dx.doi.org/10.1353/jge.2007.0002

Higgins, S., Hall, E., Baumfield, V., \& Moseley, D. (2005). A meta-analysis of the impact of the implementation of thinking skills approaches on pupils. In Research evidence in education library. London: EPPI-Centre, Social Science Research Unit, Institute of Education, University of London.

Hyerle, D. (2000). A field guide to using visual tools. Alexandria, VA: Association for Supervision and Curriculum Development.

Hyerle, D. (2001). Visual tools for mapping minds. In A. L. Costa (Ed.), Developing minds: A resource book for teaching thinking (pp. 401-407). Alexandria, VA: Association for Supervision and Curriculum Development.

Innabi, H., \& El Sheikh, O. (2007). The change in mathematics teachers' perceptions of critical thinking after 15 years of educational reform in Jordan. Education Resources Information Center. ERIC No. EJ748199.

Kelly, K., \& Irene, H. (2010). Metacognitive strategies that enhance critical thinking. Metacognition and Learning, 5(3), 251-267. http://dx.doi.org/10.1007/s11409-010-9060-6

Liaw, M. (2007). Content based reading and writing for critical thinking skills in an EFL Context. English Teaching \& Learning, 31(2), 45-87.

Magno, C. (2010). The role of metacognitive skills in developing critical thinking. Education Resources Information Center. ERIC No.EJ891309.

Mahyuddin, R., Pihie, Z., Elias, H., \& Konting, M. (2004, December). The incorporation of thinking skills in the school curriculum. Kajian Malaysia, XXII(2).

Miri, B., Ben-Chaim, D., \& Zoller, U. (2007). Purposely teaching for the promotion of higher-order thinking skills: A case of critical thinking. Education Resources Information Center. ERIC No. EJ7744448.

Nosich, G. (2009). Learning to think things through: A guide to critical thinking across the curriculum. Columbus, $\mathrm{OH}$ : Pearson Prentice Hall.

Ong, C. (2006). Implementing a thinking curriculum. In A. C. Ong, \& G. Borich (Eds.), Teaching strategies that promote thinking: Models and curriculum approaches (pp. 303-323). Asia: McGraw-Hill Education.

Ozsoy, G., \& Ataman, A. (2009). The effect of metacognitive strategy training on mathematical problem solving achievement. Education Resources Information Center. ERIC No.ED508334.

Paul, R., \& Linda, E. (2006). Critical thinking: Learn the tools the best thinkers use. Columbus, OH: Pearson Prentice Hall.

Paul, R., Linda, E., \& Ted, B. (1997). California teacher preparation for instruction in critical thinking: Research findings and policy recommendations. Sacramento, CA: California Commission of Teacher Credentialing.

Reed, J. (1998). Effect of a model for critical thinking on student achievement in primary source document analysis and interpretation, argumentative reasoning, critical thinking dispositions and history content in a community college history course. $\mathrm{PhD}$ diss., College of Education, University of South Florida.

Renner, C. E. (1996). Enriching learner language production through content based instruction. Education Resources Information Center. ERIC No. ED 411694.

Rojas, V. (2001). A view from the foxhole: Elevating foreign language classrooms. In A. L. Costa (Ed.), Developing minds: A resource book for teaching thinking (pp. 326-331). Alexandria, VA: Association for Supervision and Curriculum Development.

Savich, C. (2008). Improving critical thinking skills in history. Oakland University. Education Resources Information Center. ERIC No.ED501311.

Scanlan, S. (2006). The effect of Richard Paul's universal elements and standards of reasoning on twelfth grade composition. MA thesis. San Diego, CA: Alliant International University. 
Sezer, R. (2008). Integration of critical thinking skills into elementary school teacher education courses in mathematics. Education Resources Information Center. ERIC No. EJ816897.

Smith, K., Rook, J., \& Smith, T. (2007). Increasing student engagement using effective and metacognitive writing strategies in content areas. Education Resources Information Center. ERIC No. EJ767742.

Sokol, A., Oget, D., Sonntag, M., \& Khomenko, N. (2008). The development of inventive thinking skills in the upper secondary language classroom. Education Resources Information Center. ERIC no. EJ796707.

Stapleton, P. (2011). A survey of attitudes towards critical thinking among Hong Kong secondary school teachers: implications for policy change. Education Resources Information Center. ERIC No. EJ915705.

Swartz, R. (2001). Infusing critical and creative thinking into content instruction. In A. L. Costa (Ed.), Developing minds: A resource book for teaching thinking (pp. 266-274). Alexandria, VA: Association for Supervision and Curriculum Development.

Swartz, R., \& Sandra, P. (1994). Infusing the teaching of critical and creative thinking into content instruction. Seaside, CA: Critical Thinking Press \& Software.

Swartz, R., Arthur, L. C., Barry, K. B., Rebecca, R., \& Bena, K. (2008). Thinking-based learning: Activating students' potential. Norwood, MA: Christopher-Gordon Publishers.

Thurman, B. (2009). Teaching of critical thinking skills in the English content area in South Dakota public high schools and colleges. Education Resources Information Center. ERIC No. ED513229. 